Mei, 2019, 13-25

\title{
GENDER REPRESENTATION OF CHIMAMANDA NGOZI ADICHIE IN 'WE SHOULD ALL BE FEMINISTS'
}

\author{
Feny Anggeria \\ feny_anggeria@yahoo.com \\ Master of Linguistics, Faculty of Humanities, Universitas Airlangga
}

\begin{abstract}
Gender is the study of women and men among their roles in society. Since the year of emancipation occurs in all the country, the term gender becomes popular. Talking about gender, of course, it is the same as talking about feminism. Chimamanda Ngozi Adichie is one of the most influential women in Africa. Her speech and essay, 'We Should All Be Feminists', which serves the idea of feminism have changed the term feminism with a high balance discussion. The study of gender, in Africa, has frequently considered as a taboo because there is no equality insight between women and men. By implementing the transitivity in Halliday's SFL (Systemic Functional Linguistics), it is necessary to know the language used by Chimamanda Ngozi Adichie. The type of data in this research is quantitative and qualitative data. This study also applied Critical Discourse Analysis as the approach. Hence, the library research supports the understanding of the material which is applicable and accurate to obtain the source of the data.
\end{abstract}

Keywords: Gender, Feminism, SFL, Transitivity, CDA

\begin{abstract}
Abstrak
Gender adalah kajian tentang peran perempuan dan laki-laki di dalam masyarakat. Sejak jaman munculnya emansipasi di seluruh negara, istilah gender menjadi populer. Berbicara tentang gender, tentu, tak lepas dari yang namanya feminisme. Chimamanda Ngozi Adichie ialah salah satu tokoh perempuan yang paling berpengaruh di Afrika. Pidato dan esainya yang berjudul "We Should All Be Feminists" menjadi landasan baru tentang feminisme dan sekaligus menjadikan topik ini sebagai bahan diskusi yang sangat berimbang. Kajian tentang gender, di Afrika, seringkali dianggap tabu karena tidak ada wawasan tentang persamaan derajad antara perempuan dan laki-laki. Dengan mengimplementasikan transitivitas dalam Halliday's SFL (Systemic Functional Linguistics), perlu untuk mengetahui bahasa yang dipakai oleh Chimamanda Ngozi Adichie. Jenis data yang yang digunakan dalam kajian ini ialah kuantitatif dan kualitatif. Studi ini juga menerapkan pendekatan Kajian Wacana Kritis. Oleh karena itu, kajian pustaka mendukung pemahaman dari materi yang mana dapat diterapkan dan akurat dalam mendapatkan sumber data.
\end{abstract}

Kata kunci: gender, feminisme, SFL, transitivitas, kajian wacana kritis

\section{INTRODUCTION}

Spoken gender is mainly dedicated to all women who feel unequal in the society or small group. In Nigeria, gender by the term is important to describe young women or girl since they get along with the society and it has been forgotten. Nigeria is an extreme example of the decade. More gender has generally been used to define equality between man and woman. The term is always determined by the roles and activities that constructed by society. The issue is about black women. Most of them in 
Africa get no chance to feel educated and explored as a man. They are under the man rights and far away from being self-love. Sometimes they have to do more jobs but still, look strange to do it

If someone talks about gender, so it is mostly a case of a woman in society (Mikkola, 2017). To discuss gender matter, the word 'gender' becomes polite rather than feminism. This conventional concept always exists as long as women still assume themselves as creatures that need to be avowed in man consideration. This probably makes feminism in the position of being one of an existential theme until now. One given example, if we look back to the standard conversation of both men and women, men will be authorized as the superior to women, the minority

Recalling the year of feminism, it first took a contribution to America. In 1930's (Editors, 2019) America had a Great Depression in that year, all working women were seen as a low level in taking jobs, and they were away from men who were the rightful breadwinners. Prior to 1942 women were not allowed to serve in the military except as nurses. In that year, patriotism kept women away from feminist meeting halls. However, American's involvement in World War II marked a sea change in women's roles. In Post War Feminism, there was a young activist of feminism namely Eleanor Roosevelt. First Lady Eleanor Roosevelt was an inspiration to women, not only in the U.S but also in the world. Besides Roosevelt, Hillary Clinton is the most powerful activist in the modern era. She gained many supports from her followers to fight against 'women and inequality'. Continually, she is invited in many world discussions about feminism. These two women become an unchanged figure, and it makes a broad knowledge that feminism is still happening.

However, the gender issue that happens in Africa did not have any relation with World War, or even with America. Africa is known as the poor country in which human resource is mostly dominated by women. This one-sidedness causes the growth of women. Unfortunately, the number of women who live in Africa does not prove the equality in society because the reason of poverty leads them (Chifwafwa, 2016). According to the 2012 Gender in Nigeria Report, gender imbalances happen in many kinds of situation. More, British Council exposed in eight Northern States over 80\% of women is unable to read compared with $54 \%$ for men. $70.8 \%$ of young women aged 20-29 in the North-West are unable to read and write and only 3\% of female's complete secondary school. In property rights, women are denied legal right to own property or inherit the land. In North-East Nigeria, women own only $4 \%$ of land and just over $10 \%$ of land ownership in the South-East and South-South. Female children have no right to partake in the sharing of their father's wealth, while men have the right to own land (Abara, 2012: 5-6).

Related to this research, Chimamanda Ngozi Adichie is recently one of the most influential women in Africa. She is the author of phenomenal novels relating to the gender and feminist issue. Her works have been translated in thirty languages 
and have appeared in various publications, including The New Yorker, Granta, The O, Henry Prize Stories, The Financial Times, and Zoetrope. Her latest masterpiece, We Should All be Feminist, is published around the world in 2014, and has received numerous accolades, including winning the National Book Critics Circle Award for Fiction and Chicago Tribune Heartland Prize for Fiction: and being named one of The New York Times Ten Best Books of the Year.

We Should All Be Feminist is a Ngozi's essay which published in the form of a book in 2014. Before the publication, the essay, which had not completed yet, was used to attend TEDxEuston in 2013. The essay reviews Ngozi's idea of experiencing inequality in the land of Africa. It also contains a discussion between men and women within the poor background of gender in Nigeria. In nowadays gender in Africa still looked under the definition. Oppression by man, family, and society can cause bad interpretation that women cannot connect to the world. That way it still happened

Money and Hampson (1955) defined the term gender as what a person says or does to reveal that he or she has the status of being boy or girl, man or woman (masculinity or femininity of a person). Xue (2008) explained that gender is a complex issue, constituents of which encompass styles of dressing, patterns of moving as well as ways of talking rather than just being limited to biological sex. Over the years, the perception of the issue 'gender' has been changing and developing from essentialism to social constructionism. Essentialism suggests that gender is biological sex, by contrast, social constructionism suggests that gender is constructed within a social and cultural discourse. Due to its complex nature, gender intrigues numerous debates over the extent to which gender is a biological construct or environment ideas.

In fact, gender can also bring the issue of stereotype. The stereotype is something makes the person labeled to a certain group or community. Kiausiene, et al. (2011) mentioned gender stereotype consists of beliefs about psychological traits and characteristics of, as well as the activities appropriate to, men or women. Gender stereotypes are very influential. Therefore, gender roles furnish the material for gender stereotypes (The Stereotype Trap, 2000). Stereotype, on the other hand, has a huge impact related to gender. In Africa, most women are stereotyped as the submissive, while men are dominant. Stereotype also relates to the culture that shaped a certain group or community. For example black women conventionally point out the African girl. To reject the stereotype between culture to culture is difficult. The only way to leave the idea is to broaden mind with Critical Discourse Analysis. By doing Critical Discourse Analysis, people can share the same way of thinking of gender in a wider sense.

Fairclough and Wodak (1997: 271-80) summarize the main tenets of CDA as follows:

1. CDA addresses social problems

2. Power relations are discursive 
3. Discourse constitutes society and culture

4. Discourse does ideological work

5. Discourse is historical

6. The link between text and society is mediated

7. Discourse analysis is interpretative and explanatory

8. Discourse is a form of social action.

Ngun, et al (2010) Gender is globally not determined biologically, as a result of sexual characteristics of either women or men, but is constructed socially. It is wide because it directly connects men and women's relation in the term 'inequality'. The issue is also strongly recommended because it fulfils further research by developing another issue of Critical Discourse Analysis. Systemic Functional Linguistics (SFL) is an approach to language developed mainly by Halliday. While SFL accounts for the syntactic structure of language, it places the function of language as the central point. In analysing this research, Breeze (2011) explained SFL is the main solution to do research in the field of Critical Discourse Analysis. This is so called because SFL provides the finding of the dominant process that used as the analysis in this study.

Finally, these are the explanatory questions. The questions are how the transitivity work in We Should All Be Feminists, what dominant gender of Chimamanda Ngozi represent. The goal is to analyse the transitivity that most used by Chimamanda Ngozi in We Should All be Feminists and to reveal the dominant gender represented by Chimamanda Ngozi in We Should All Be Feminists.

\section{LITERATURE REVIEW}

There are some researchers attempting to analyse gender in the form of article and paper. The first researcher is Bergam (2014), a student of Swedish School of Sport and Health Science, with his research entitled 'Construction of Gender Equality in Swedish Sport: Discourses and Subject Position in Conversations about Gender Equality with Male Sports Coaches and Leaders'. The analysis offers a critical conversation between male coaches and leaders in the sports team. Research indicates a notable gap between what is said and done at the central level and locally. Research also indicates attitude problems: gender equality is often seen as an insignificant or unnecessary issue. The aim is to investigate the construction of gender equality with 50 male coaches and leaders in Swedish sports. This approach is motivated by the fact that gender equality-related to sports research in Sweden seldom focuses on men and masculinities.

Second, Satiti (2012), a student from Jember University, with her research entitled 'Gender Representation of Margaret Thatcher in The Iron Lady Movie: A Critical Discourse Analysis on Transitivity. The objective of this study is to examine the language used by the character of Margaret Thatcher in a movie entitled The Iron Lady. This research reveals her dominant gender represented in the movie and the 
existence of gender equality in it. The investigation is based on Halliday's Systemic Functional Grammar attentively in the verb processes included in the transitivity system. In addition, the theory of Critical Discourse Analysis is applied to reveal the goal through the dominant verb processes produced by the character. The nature of this study is statistical, descriptive, and interpretative. Those methods of analysis are applied to quantitative and qualitative data through the technique of documentary (bibliographical) study as the method of collecting data. The finding of this thesis exposes that Margaret Thatcher in this movie dominantly represents masculinity rather than femininity. It deals with the dominant verb which is found in the analysis is integrated into the material process. Through the analysis, it is unquestionable that gender equality within the character of Margaret Thatcher cannot be proved. In contrast, this movie shows the phenomenon of gender inequality.

The last researcher is Wang (2010), an Associate Professor in Northwest Normal University comes with his project entitled 'A Critical Discourse Analysis of Barack Obama's Speeches'. Wang starts his project by using Halliday's Systemic Functional Linguistic, in terms of the three metafunctions: ideational function, interpersonal function, and textual function. His purpose is to find out the formal features of Barack Obama's speeches and to explore the relationship between language, ideology, and power. Additionally, Wang is also eager to figure out the use of the power of speeches to persuade the public to accept and support his policies.

These researches give a big contribution to this research. It provides some broad views of Critical Discourse Analysis and its solution in case of understanding the concept in the previous research. While the first two research supports an idea about gender and its perspective, the third one answers the implementation of Halliday's Systemic Functional Linguistic. Coming from those two analytical descriptions, it is discussed in this recent research.

In the linguistics field, discourse is traditionally understood to mean language as 'text' or a stretch of language perceived to be meaningful, unified, and purposive (Nunan, 1993: 6). Discourse plays an important role. It is because discourse handles knowledge through word and expression. On the other hand, Critical Discourse Analysis is also understood as the production of social practice drawn upon a situational context is divided into two categories: both are written and spoken discourse. The situation of spoken and written discourse can be divided into two contexts. They are the context of culture and context of the situation (Wodak, 1997:6). These two contexts under the term 'gender' bring social power, inequality, and dominance. It supports the statement of Dijk (1985: 352) that 'Critical Discourse Analysis is a type of discourse analytic research that primarily studies the way social power abuse, dominance, inequality are enacted, reproduced, and resisted by talk and written text in the social and political context'. With such dissident research, Critical Discourse Analysis analysts take an explicit position, and, thus, want to understand, expose, and ultimately resist social 
inequality.

Systemic Functional Linguistics is a theory of language centered on the notion of language function. While SFL accounts for the syntactic structure of language, it places the function of language as central as what language does, and how it does it, in preference to more structural approaches, which place the elements of language and their combinations as central. As the basis of Critical Discourse Analysis, SFL analyses a variety of text, whether it is written text or spoken text, by looking at how the grammar is used (Arindo, 2013: 12). SFL is compulsory for CDA because SFL interprets language as making meaning. The meaning includes ideational meaning, interpersonal meaning, and textual meaning. Ideational meaning is to express language through the perception of people towards the world. Interpersonal meaning is to express and understand feelings, attitude, and judgment, while textual meaning is to relate the situational contexts through an aspect of communication (Mayr, 2008: 17). In brief, CDA and SFL can examine the system of linguistic choice in Chimamanda Ngozi Adichie's We Should All Be Feminists. The use of SFL is the main solution to do research in the field of Critical Discourse Analysis. It is because both CDA and SFL enable the researcher to unfold social problem, which is gender and feminism through the use of language.

Experiential Meaning is classified as one of the three metafunctions. This part of metafunction uses a grammatical system of transitivity. Although sharing the traditional view of transitivity that the focus is on the group. Systemic Functional Grammar refers to the system as describing the whole clause (Thompson, 2004). Experiential meaning is particularly expressed through the system transitivity or process type.

Transitivity analysis is one of the functions of a clause which represent experience. In the SFL model, a representation of experience involves verb processes, participants, and circumstances. These are called ideational metafunction. Intransitivity, language operates with some systems of types of process, the process of doing and happening, sensing and saying, being and having.

There are six types of process (Halliday: 1994: 109). They will be elaborated below:

a. Material Process

The material process is the process of doing and happening.

\begin{tabular}{|c|c|c|}
\hline My mother & Cleans & The floor \\
\hline Actor & Pro; Material & Goal \\
\hline
\end{tabular}

b. Mental process

The mental process is the process of seeing

\begin{tabular}{|c|c|c|}
\hline $\mathrm{He}$ & feels & Tired \\
\hline Senser & Pro; Mental & Phenomenon \\
\hline
\end{tabular}


c. Relational process

The relational process is the process of being.

\begin{tabular}{|c|c|c|}
\hline My mother & Is & Unskilled \\
\hline Carrier & $\begin{array}{c}\text { Pro; Relational Attrib- } \\
\text { utive/ Identifying }\end{array}$ & Attributive \\
\hline
\end{tabular}

d. Verbal process

The verbal process is the process of saying

\begin{tabular}{|l|l|l|}
\hline Ratna & tells & Me the truth \\
\hline Sayer & Pro; Verbal & Receiver \\
\hline
\end{tabular}

e. Behavioural process

The behavioural process is the process of physiological behaviour like breathing and laughing

\begin{tabular}{|c|c|c|}
\hline She & Observes & The result of the research \\
\hline Actor & Pro; Material & Goal \\
\hline
\end{tabular}

\section{f. Existential process}

The existential process represents something has existed and happened

\begin{tabular}{|c|c|c|}
\hline There & Is & a book \\
\hline & Pro; Existential & Existent \\
\hline
\end{tabular}

As stated below (Mills and Mullany, 2011, p. 2) in Montoro, Rocio (2014: 348):

"It is important to point out that language and gender studies do not have to be feminist in orientation. Leading language and gender researcher Deborah Cameron (2006) has pointed out that non-feminist studies will present descriptive linguistic accounts of gender and language, often detailing processes of language shift or change or present descriptions of how women and men use language in specific locations at particular points in time. The key difference between this knowledge-gathering research and 'feminist' research is that the latter has a specific political purpose by focusing on gender as a social, political and ideological category".

Concerning with those, Rocio Montoro in Routledge Handbooks (2014: 349) declares:

"As far as language and gender research is concerned, the most influential scholarly work of the past has generally centered around three major axes (because of space constraints, I am restricting my discussion to work published in the latter half of the twentieth century onwards), each one representing a particular standpoint concerning the discrepancies between men and women's linguistic practices: the deficit theory, the dominance theory and the difference theory".

The elaboration of those three theories is explained below:

a. The Deficit Theory, theory illustrates the earliest stance regarding women's linguistic 
characteristics. The characteristic is ineffective and 'lacking' when compared to that of men. In the situation of powerlessness in society, women are especially seen in relation to males. The use of lexical hedges or fillers usually appears (e.g. you know, sort of, well, you see) (Montoro, Rocio: 349).

b. The Dominance Theory, theory which is based on men's dominant position in society, with women being portrayed as " weak, helpless victims of patriarchy that forces them to act in weak, passive, irrational or ineffective ways" (Freeman \& McElhinny, 1996: 236). Dominance is seen to be in the same category as 'weakness', 'passivity' and 'deficiency' (Uchida, 1998:286).

c. The Difference Theory, a theory which sees men and women belonging to different subcultures because they are socialized differently from childhood, have different ways of communicating from one to another .e.g. women are more supportive in conversation because they're brought up to be facilitators (Fishman, 1983).

The use of written data in feminist forms of text linguistics, and especially the concerted attention given to written discourse genres in which issues of gender and power are prominent features. Women and their speech have been measured against male standards and found to be deviant and deficient, just as not too long ago there was something 'wrong' with working-class speech. But, in this case, Chimamanda Ngozi Adichie does not the only goal to the inequality, but also the ideology. People with a traditional gender role ideology believe that women should give priority to family responsibilities, while men should prioritize work responsibilities. Gender role ideology is a historical construction whose meaning is derived from each culture or context and is substrate upon which different meaning is given to the sexes (Pastor, 1998).

In We Should All Be Feminists, gender highly shows in understanding the significance of womanhood. Womanhood is generally something which is taboo. But recalling the new feminism, it can take action with gender together, because the term gender and feminism have been so far changed. The change makes gender in a progressive sense to be discussed in most of the aspect of womanhood. It can be good news to women all over the world, that they indeed are the most important thing in society.

In this research, quantitative and qualitative research is applied. Quantitative research is the systematic empirical investigation of observable phenomena via statistical data. It explains phenomena by collecting numerical data that are analysed using mathematically based method (Gunderson, 2000). The objective of quantitative research is to develop and employ mathematical models, theories or hypotheses pertaining to the phenomena.

Qualitative research is non-systematic empirical observation. It means to get the exact completion inside the research, it is necessary to reach an actual source from the library as guidance instead of using a statistical method. The type of data is quantitative 
and qualitative data. The method of data collection uses the descriptive, statistical, and interpretative method. The descriptive method is chosen to select clauses. The statistical method is used to count the verb process. The interpretative method is to elucidate the way of gender inequality enacting We Should All Be Feminists.

\section{RESULT\&DISCUSSION}

The following diagram is the reckoning of a process type.

\begin{tabular}{|c|c|}
\hline Process Type & Clause \\
\hline Material & 295 \\
\hline Relational & 209 \\
\hline Mental & 50 \\
\hline Verbal & 23 \\
\hline Behavioral & 9 \\
\hline Existential & 2 \\
\hline TOTAL & $\mathbf{5 8 8}$ \\
\hline
\end{tabular}

Based on the result above, the material process is the dominant process. The speech or the essay consists of 588 clauses, 295 material processes, 209 relational processes, 50 mental processes, 23 verbal processes, 9 behavioural processes, and 2 existential processes.

For material process, the actor must be a human representative, while the presence of the goal is various. The participants in the material process involve actor (the doer), goal (attached participant), beneficiary, and range. The material process is explained below.

So $\mathbf{I}$ brush it aside

and continued to argue.

And the first thing that I planned to do

when I got home

was to look up "feminist" in the dictionary.

The word "I" emphasizes the actor who leads the activities in those sentences. Their productive activities bring their identities (Fairclough in Wodak, 2001: 122).

I was impressed with the particular theatrics of the man

who found us a parking spot that evening.

And so as we were leaving,

I decided to leave him a tip.

I opened my bag,

put my hand inside my bag

brought out my money

that I had earned from doing my work,

And I gave it to the man.

We must raise our daughter 
Besides, the second most applied type is relational processes.

Now men and women are different.

We have different hormones,

we have different sexual organs,

we have different biological abilities:

women can have babies,

men have, at least not yet.

Men have testosterone,

and are in general physically stronger than women.

There are slightly more women than men in the world,

About $52 \%$ of the world's population is female.

To compare between women and men, Adichie uses relational process (are, have, is) to describe what makes them different in some ways. In exploring the relational process, descriptive statements are very needed.

The third process is the mental process.

You hate men,

you hate bras,

you hate African culture, that shorts of thing.

The fourth process is verbal processes.

My teacher said at the beginning of the term

Then to my surprise, my teacher said that.

“Oh, but women can just say 'no' to all of this".

In a verbal process, Adichie certainly has experience with other people who have touched feminism with her. The word 'say' is used to give an account of what society has done with Adichie.

Based on gender, Adichie provides a brief explanation of women rather than men. This is so called because related to the quality of women in Africa, gender does not exist as it is should be. In addition, employing SFL as the theory in this research can prove the gender in Africa.

To answer those questions, the data implement that she uttered 8 processes to prove that she is biased to the women. Adichie would like to do the action with the word 'we' which represents herself and women.

1 Gender matters everywhere in the world, but I want to focus on Nigeria, and on Africa in general

2 And I would like today to ask

3 that we begin to dream about and plan for a different world.

4 We must raise our daughters differently.

5 We must also raise our sons differently. 
6 We do a great disservice to boys i

7 how we raise them.

8 We stifle the humanity of boys.

Similarly, there are 6 verb processes in sentences Adichie uses to define man as what she has done.

1 We define masculinity in a very narrow way.

2 Masculinity becomes this hard small cage

3 and we put boys inside the cage.

4 We teach boys to be afraid of fear.

5 We teach boys to be afraid of weakness, of vulnerability.

6 We teach them to mask their true selves

Again, there are 4 verb processes that describe women as a part of a culture in Nigeria.

1 I have beautiful twin nieces who are 15 who live in Lagos.

2 So, what is the point of culture?

3 but also culture is really about the preservation and continuity of a people. In my family,

4 I am a child.

In addition, the main focus of 'women language' was on its 'powerlessness,' perceived as obtaining from the 'weak' stance or position those women were thinking (Eckert and Ginet, 2003: 158). While women language is classified as the powerlessness, men language can also be classified as the contrary of it. Men language tends to be the opposite of the women language. It does not include feeling when men speak. It is considered to be 'powerful' and 'directness'.

After all, Chimamanda Ngozi Adichie in her speech or essay can demonstrate gender inequality within herself in view of the fact that femininity is always in powerless. Her choice of verbs likely represents her achievements in making women has to be appreciated by the men.

\section{CONCLUSION}

After doing the investigation in Chimamanda Ngozi Adichie 'We Should All Be Feminists', finally, the conclusion can draw a general implication of the study. In detail, the results of the analysis performed in this chapter are fully presented to answer the questions in the introduction. The answer is clearly found, and the data is valid. It is rooted in Critical Discourse Analysis. 'We Should All Be Feminists' is criticized to find out the dominant gender that occurs in Chimamanda Ngozi Adichie. The language that is used by Adichie has proven the inequality between men and women.

In the first place, the answer to the first question, how does the transitivity work 
in We should All be Feminist, has been dealt that material process is mostly used than the other processes. The finding is revealed through the quantitative analysis with the number of verb processes. Personally, taking action of women is one of her jobs in society. This action hugely contributes to the language that she used in her speech and her essay. The material process that is explained is: And I would like today to ask that we begin to dream about and plan for a different world. It means women in Nigeria always want to ask about their dream. They want to make a dream as their spoken language heard by everybody.

We must raise our daughters differently. The priority of being a mother performs as one single mother that must grow the children alone. This is taken as the consequences of being a woman in society.

The second answer is what dominant gender does Chimamanda Ngozi represent in We Should All Be Feminists? This answer is related to the language that she performs in her speech and her essay. Through the analysis, it can be concluded that she mostly highlights her femininity in her character. It means that gender representation refers to the female gender. As the material process is the pattern, the other words: We must also raise our sons differently and We do a great disservice to boys. Those two sentences explain that women always do the right hand to man or boys.

Finally, this research can be expected to be useful for further research, especially in the scope of Critical Discourse Analysis study in analyzing the gender issue. Hopefully, it can also be contributed to women's study. Some research and activist that are aware of women issue in the world will gain the positive side of women in the society, it is given to every woman and world campaign. To society, living in our country, Indonesia, we can learn and to be a critical thinker whether women and men should be a support system in our country

\section{REFERENCES}

Arindo, Yesi. 2013. Racism in Lincoln-Douglas Debate in Ottawa in 1858: A Critical Discourse Analysis. Jember: Jember University.

Cameron, D. 2006. Language and sexual politics. London: Routledge.

Chifwafwa, E. (2016, November 13). IS GENDER INEQUALITY IN AFRICA ABOUT CULTURE OR IS IT ABOUT POVERTY? Diambil kembali dari SIANI: https:// www.siani.se/blog/gender-inequality-africa-about-culture-or-it-about-poverty/

Eckert, P \& Ginet, M. S. 2003. Language and Gender. New York: Cambridge University Press.

Freeman, R. D. \& McElhinny, B. (1996). "Language and Gender". In S. Mckay \& N. Hornberger (eds.), Sociolinguistics and Language Teaching, pp. 218- 280. Cambridge: Cambridge University Press.

History.com Editors. (2019, April 15). Great Depression History. (A\&E Television Networks) Retrieved from HISTORY: https://www.history.com/topics/great- 
depression/great-depression-history

Lazar, Michelle. M. 2010. Feminist Critical Discourse Analysis: Articulating Feminist Discourse. UK: Routledge.

Mayr, Andrea, 2008. Language and Power: An Introduction to Institutional Discourse. London: Continuum.

Mikkola, M. (2017, October 27). Feminist Perspectives on Sex and Gender, Winter 2017. (E. N. Zalta, Editor, \& S. U. Metaphysics Research Lab, Producer) Retrieved from The Stanford Encyclopedia of Philosophy: https://plato.stanford. edu/archives/win2017/entries/feminism-gender/

Mills, S. and Mullany, L. 2011.Language, Gender and Feminism.Theory, Methodology, and practice.London and New York: Routledge.

Richard, J.C \& Schmidt, R. 2002. Longman Dictionary of Language Teaching and Applied Linguistics: 3th Edition. UK: Pearson Educational Limited.

Satiti. P. D. 2012. Gender Representation Of Margaret Thatcher in The Iron Lady Movie: A Critical Discourse Analysis on Transitivity. Jember: Jember University.

Sunderland, J. 2006. Language and Gender. USA: Routledge.

Uchida, A. (1998). "When 'Difference' is 'Dominance': A Critique of the 'Anti-power Based' Cultural Approach to Sex Differences". In D.Cameron (ed.), The Feminist Critique of Language. USA \& Canada: Routledge.

Xue, Changxue. 2008. Critically Evaluate The Understanding of Gender as Discourse. China: Yanshan University. 